\title{
Mortality from asthma in the state of S. Paulo, Brazil (1970-1992)
}

\author{
Paulo Andrade Lotufo, Isabela Judith Martins Benseñor and Cecilia Amaro de Lolio \\ Departamento de Clínica Médica da Faculdade de Medicina da Universidade de Săo Paulo. \\ São Paulo, SP - Brasil (P.A.L., IJ.M.B.), Departamento de Epidemiologia da Faculdade de \\ Saúde Pública da Universidade de São Paulo. São Paulo, SP - Brasil (C.A.L.)
}

\begin{abstract}
Mortality from asthma has shown important variations over time in several countries. In Brazil, a mortality study performed in the 60s, covering the cities of $\mathbf{S . P a u l o}$ and Ribeira Preto, and other ten cities showed that $\mathrm{S}$.Paulo presented the lowest death rate from asthma among of them all. It was declded to study the time trends of deaths from asthma and from the whole set of respiratory diseases from 1970 to 1992, in the population aged 15-34 yrs. old in the State of S.Paulo, as well as to compare them with those of other countries. Asthma mortality rates during the 23 years of observation since 1975, showed an oscillatory declining pattern with a peak of deaths in the initial years. The linearization of the curve allows the calculation of Pearson's correlation coefficient that was significantly negative, suggesting a decline in the mortality over this period, mainly in the 5-9 yrs. old and 30-34 yrs. old strata. The segmentation of data between the period of ICD-9, 1970 to 1978, and of ICD-9, 1979 and subsequent years, shows that there is stability within each period, In all age-groups, except for that of 5-9 yr. olds between 1970-1978. Comparing the rates of the population aged $15-34$ yrs. old for the State of S. Paulo, Brazil, with trends observed in 14 other countries, an intermediate pattern for the first triennial period (1970-1972) as well as for the subsequent triennial periods, emerges. A prevalence study of asthma, a follow up program meant for using emergency rooms and a survellance of deaths due to all respiratory diseases and specifically to asthma are strongly recommended.
\end{abstract}

Asthma, mortality. Mortality rate.

\section{Introduction}

Mortality from asthma has shown important variations over time in several countries. The rise of death rates between 5 and 35 years old in the $60 \mathrm{~s}$ in England and Wales, New Zealand and Australia is considered to constitute the first epidemic of deaths due to asthma ${ }^{10.11}$.

In Brazil, a mortality study undertaken in the 60 s, involving the cities of S.Paulo and Ribeirāo Preto, both in the State of S.Paulo, Brazil, together with eight other Latin-American cities, Bristol (UK) and San Francisco (USA) showed that S. Paulo presented the lowest death rate from asthma of the twelve cities ${ }^{17}$. When all the respiratory diseases are taken into consideration, Ribeirāo Preto and S.Paulo fell respectively into the fifth and sixth places for males, and the sixth and eighth places for females. The importance of asthma and of the respiratory diseases as cause for the utilization of medical care facilities in the State of S.Paulo has grown and led to an intervention program in the second half of the $80 \mathrm{~s}^{18}$.

It was decided to study the time trends of deaths from asthma and from the whole set of respiratory diseases in the population aged 5-34 yr. old in the State of S.Paulo as well as to compare them with those of other countries.

\section{Methodology}

Deaths due to asthma and to the whole spectrum of respiratory diseases were studied in the

Reprints: Paulo Andrade Lotufo - Departamento de Clinica Médica. Ambutatorio Geral e Didática, $4^{\circ}$ andar, PAMB-AGD. Av. Dr. Enéas Carvalho de Aguiar, 155 - 05403-900 - São Paulo, SP - Brasil - Fax: (011) 280.1679.

Ediçāo subvencionada pela FAPESP. Processo 95/2290-6.

Recebido em 8.3.1995. Aprovado em 18.9.1995. 
population of the State of S.Paulo, aged between 5 and 34 yrs. old, grouped in 5-year strata. The variation of proportional mortality, the trends of specific death rates in the period as well as an international comparison with the triennial rates are presented.

Deaths: The sources of data were the tables of deaths compiled by the "Fundação Sistema Estadual de Análise de Dados" FSEADE ${ }^{8}$ condensed into 50 main causes of death. Of the total of deaths, deaths as assigned to asthma were those coded 490 to 493 International Classification of Diseases, 8th Revision ${ }^{15}$ (ICD-8), 1970 to 1978 , and 9th Revision ${ }^{16}$ (ICD-9), 1979 to 1992. Deaths due to respiratory diseases were those of the appropriate Chapter of ICD. The use of the death certificate as a suitable instrument for epidemiological purposes has been validated in the city of S. Paulo on two occasions with acceptable results and compares to those of other cities as trustworthy ${ }^{13,17}$.

Population: Population data were obtained from the $8^{\text {th }}, 9^{\text {th }}$ and $10^{\text {th }}$ Demographic Censuses (carried out, respectively, in 1970, 1980 and
$1991)^{5,6,7}$. The data for the inter census years have been calculated using linear interpolation from the census years.

Age standardization of rates: The direct method for age standardization was performed and the population of the State of S. Paulo in the census year of 1980 standard was used as the pattern ${ }^{6}$.

Statistical analysis: was performed using the $t$ test of Student with $\mathrm{n}-2$ degrees of freedom applied to the study of correlation' ${ }^{1}$.

\section{Results}

Figure 1 shows the time trend of the mortality from asthma and reveals that during the 23 years of observation, the initial years were those of highest rates. An oscillatory declining behavior is observed as from 1975.

The linearization of the curve allowed the calculation of Pearson's correlation coefficients (Table 1) that were significantly negative, suggesting a decline of the mortality in this period, main-

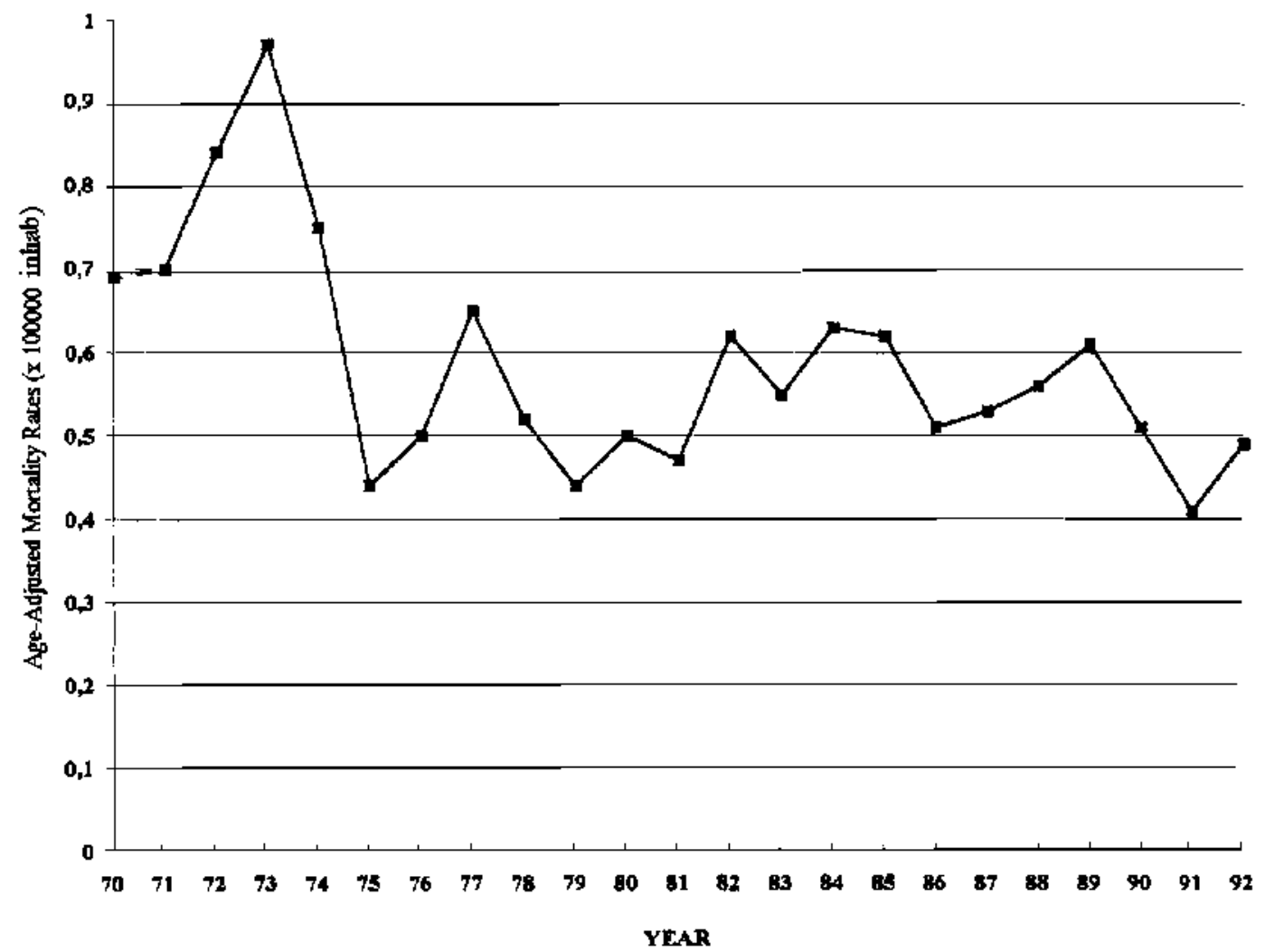

Figure 1- Mortality trends (age-adjusted mortality rates per 100,000 inhabitants) from asthma between 5 and 34 years of age in the State of S. Paulo from 1970 to 1992. 
ly in the 5-9 year-old and 30-34 year-old strata. The segmentation of data between the period of ICD-9, 1970 to 1978 , and of ICD-9, 1979 and subsequent years, shows that there is stability in each period, in all age-groups, with the exception of the 5-9 year-olds between 1970-1978.

For all respiratory diseases, the mortality trend (Figure 2) also showed a peak of occurrence at the beginning of the $70 \mathrm{~s}$. During the whole period (Table 1), age-standardized death rates showed a significant decline, mainly between the ages of 5 and 14. The analysis made in the light of the two Revisions of the ICD, does not show any alteration in the general rates, with the exception of the 5-9 year-olds age group in both moments, showing that in this age group, the decline of rates was continuous and consistent.

Comparing the rates of the population aged 534 yrs. old for the State of S.Paulo, Brazil, with trends observed in 14 other countries (Table 2), an intermediate pattern is shown both for the first triennial period (1970-1972) as well as for the subsequent triennial periods.

\section{Discussion}

Data obtained for the State of S.Paulo indicate that there is no rise in death rates from asthma such as that described for other countries, the contrary (a decline) being observed. The only exception was for the years 1972-1973. Although there was a meningitis epidemic during those years, this does not fully explain why the epidemics continued until 1975.

There are, however, limitations to this kind of data, due to the use of groupings, alterations (minimal but existent) between ICD-8 and ICD-9 in relation to asthma, and the validation of death certificates. The utilization of the grouping instead of

Table 1 - Pearson's coefficients of correlation from asthma mortality rates and all respiratory diseases(ARD) from 1970 to 1992 and during ICD-B (1970-78) and ICD-9 (1979-92) NS= Not significant

\begin{tabular}{|c|c|c|c|c|c|c|}
\hline \multicolumn{3}{|c|}{$1970-92$} & \multicolumn{2}{|c|}{$1970-78(I C D-8)$} & \multicolumn{2}{|c|}{$1979-92$ (ICD-9) } \\
\hline Age & Asthma & AFD & Asthma & ARD & Asthma & ARD \\
\hline $\begin{array}{c}5-9 \\
10-14 \\
15-19 \\
20-24 \\
25-29 \\
30-34 \\
5-34\end{array}$ & $\begin{array}{l}-0.61^{*} \\
-0.07^{\mathrm{NS}} \\
-0.15^{\mathrm{NS}} \\
-0.40^{\mathrm{NS}} \\
-0.03^{\mathrm{NS}} \\
-0.59^{*} \\
-0.55^{*}\end{array}$ & $\begin{array}{l}-0.92^{*} \\
-0.52^{*} \\
-0.21^{\mathrm{NS}} \\
-0.03^{\mathrm{NS}} \\
-0.07^{\mathrm{NS}} \\
-0.46^{\mathrm{NS}} \\
-0.63^{*}\end{array}$ & $\begin{array}{l}-0.75^{\prime} \\
-0.18 \mathrm{Ns} \\
-0.07 \mathrm{Ns} \\
-0.56 \mathrm{NB} \\
-0.28 \mathrm{Ns} \\
-0.36 \mathrm{Ns} \\
-0.54 \mathrm{Ns}\end{array}$ & $\begin{array}{l}-0.72^{*} \\
-0.28 \mathrm{Ns} \\
+0.51 \mathrm{Ns} \\
-0.13^{\mathrm{Ns}} \\
+0.02 \mathrm{Ns} \\
+0.27 \mathrm{Ns} \\
-0.08 \mathrm{Ns}\end{array}$ & $\begin{array}{r}-0.20 \mathrm{Ns} \\
0.07 \mathrm{Ns} \\
-0.09 \mathrm{Ns} \\
-0.01 \mathrm{Ns} \\
0.36 \mathrm{Ns} \\
-0.17 \mathrm{Ns} \\
-0.05 \mathrm{Ns}\end{array}$ & $\begin{array}{l}-0.76^{*} \\
-0.29^{\mathrm{Ns}} \\
+0.15^{\mathrm{Ns}} \\
+0.55^{* *} \\
+0.74^{*} \\
+0.44^{\mathrm{Ns}} \\
+0.34^{\mathrm{Ns}}\end{array}$ \\
\hline
\end{tabular}

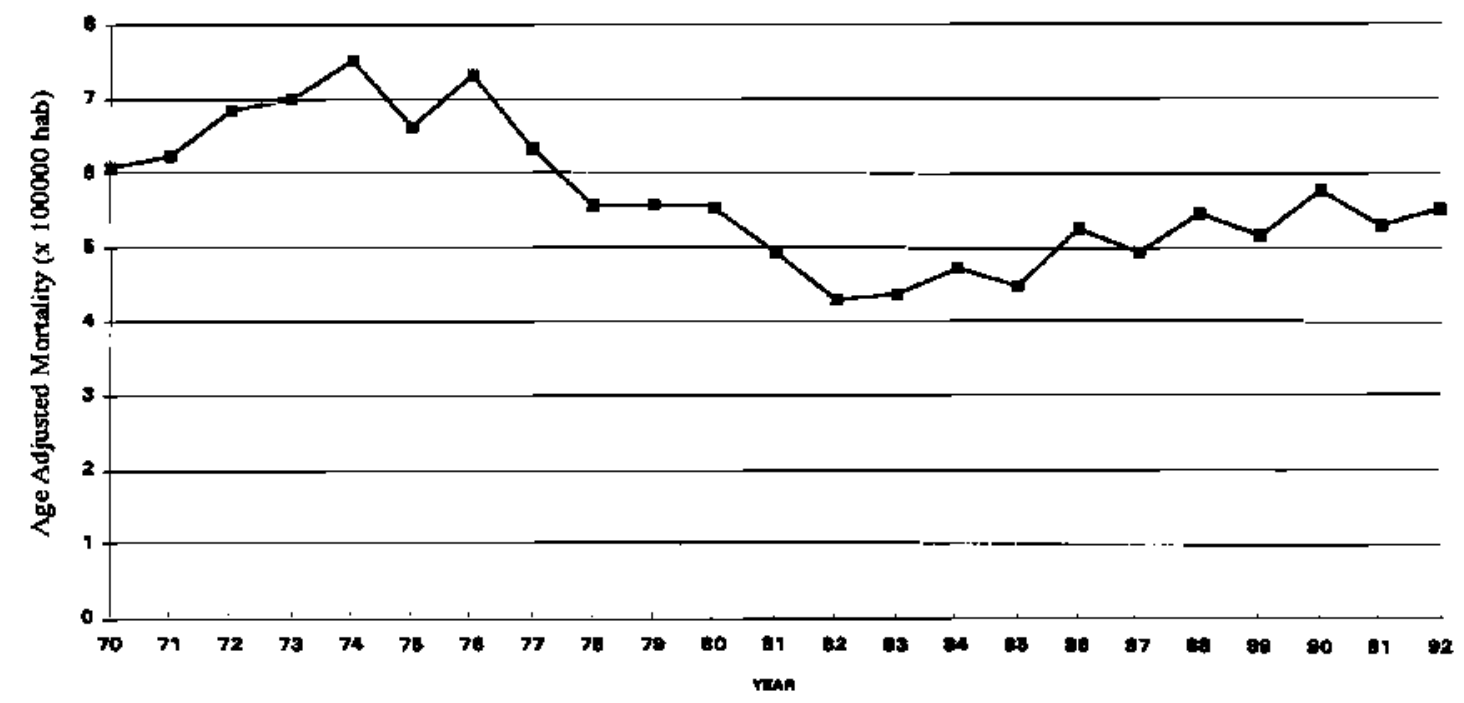

Figure 2- Mortality trends (age-adjusted mortality rates per 100,000 inhabitants) from all respiratory diseases between 5 and 34 years of age in the State of S. Paulo from 1970 to 1992. 
Table 2 - Comparing asthma mortality rates in the State of S. Paulo and in other Countries (adapted from \#10).

\begin{tabular}{|c|c|c|c|c|c|c|c|}
\hline $\begin{array}{l}\text { Country } \\
\text { (number of } \\
\text { deaths) }\end{array}$ & $70-72$ & $73-75$ & $76-78$ & $79-81$ & $82-84$ & $\begin{array}{l}\Delta 76-78 \\
/ 82-84(\%)\end{array}$ & $\begin{array}{l}\Delta 79-81 / \\
82-84(\%)\end{array}$ \\
\hline $\begin{array}{l}\text { N.Zealand } \\
(21-68) \\
\text { Singapore }\end{array}$ & 1.93 & 1.38 & 2.86 & 3.63 & 2.67 & -7 & -28 \\
\hline $\begin{array}{l}\text { (6-24) } \\
\text { Australia }\end{array}$ & 1.27 & 0.60 & 0.78 & 0.62 & 0.91 & +17 & +47 \\
\hline $\begin{array}{l}(54-106) \\
\text { Japan }\end{array}$ & 1.18 & 1.13 & 0.91 & 0.97 & 1.09 & +20 & +12 \\
\hline $\begin{array}{l}\text { (180-532) } \\
\text { England }\end{array}$ & 0.84 & 0.49 & 0.40 & 0.36 & 0.42 & +5 & +17 \\
\hline $\begin{array}{l}\text { (113-199) } \\
\text { São Paulo }\end{array}$ & 0.82 & 0.59 & 0.60 & 0.76 & 0.86 & +43 & +13 \\
\hline $\begin{array}{l}(54-110) \\
\text { former } W\end{array}$ & 0.51 & 0.48 & 0.39 & 0.33 & 0.44 & +12 & +33 \\
\hline $\begin{array}{l}\text { Germany } \\
(108-227) \\
\text { lsrael }\end{array}$ & 0.44 & 0.51 & 0.66 & 0.82 & 0.83 & +26 & +1 \\
\hline $\begin{array}{l}(0-8) \\
\text { Fintand }\end{array}$ & 0.35 & 0.41 & 0.15 & 0.15 & 0.38 & +153 & +153 \\
\hline $\begin{array}{l}(1-11) \\
\text { Sweden }\end{array}$ & 0.32 & 0.26 & 0.24 & 0.13 & 0.16 & -33 & +23 \\
\hline $\begin{array}{l}(8-25) \\
\text { Switzerland }\end{array}$ & 0.32 & 0.32 & 0.37 & 0.66 & 0.46 & +24 & -30 \\
\hline $\begin{array}{l}(5-13) \\
\text { USA }\end{array}$ & 0.30 & 0.26 & 0.37 & 0.25 & 0.23 & -38 & -8 \\
\hline $\begin{array}{l}(183-408) \\
\text { Holland }\end{array}$ & 0.29 & 0.22 & 0.19 & 0.26 & 0.34 & +78 & +31 \\
\hline $\begin{array}{l}(6-25) \\
\text { Canada }\end{array}$ & 0.21 & 0.24 & 0.18 & 0.25 & 0.30 & +67 & +20 \\
\hline $\begin{array}{l}(21-62) \\
\text { France }\end{array}$ & 0.20 & 0.28 & 0.32 & 0.40 & 0.48 & +50 & +20 \\
\hline$(33-91)$ & 0.20 & 0.28 & 0.25 & 0.25 & 0.29 & +16 & +1 \\
\hline
\end{tabular}

the word "asthma" alone may have had as a consequence an over notification of asthma; however, the four codes, from the point of view of the clinician, in the age-group studied, indicate the same physiopathological phenomenon.

The alteration observed as between ICD- 8 and ICD-9 was of no importance for this study because the category "asthmatic bronchitis" changed its code from 490 (ICD-8) to 493 (ICD-9), i.e., it remained within the same grouping.

In Brazil, two reliability studies of deaths from asthma were undertaken: the first one ${ }^{17}$, in the $60 \mathrm{~s}$, disclosed an over-notification of the diagnosis of asthma, when the correct word should be bronchitis. This was taken into consideration above when the grouping 490-493 was examined. The second study undertaken during the $70 \mathrm{~s}^{13}$ revealed an important undernotification of asthma, with a diagnostic deviation towards pneumonia. This latter study revealed that the diagnosis "pneumonia" showed great imprecision, confounding the way of dying with the underlying cause of death.

The comparison with data of mortality from diseases of the respiratory system, the pneumonias, revealed that, although there are similarities, the pattern over time differs from that of asthma, although in both pathologies there has been a decline.

A comparison with data from foreign countries reveals that the State of S.Paulo presented rates superior to those of the United States and Europe with the exception of England \& Wales throughout this period, showing that the importance of asthma as an underlying cause of death, if not significant in terms of proportional mortality, is important when compared analytically with that of other countries. The Brazilian experience (in the State of S. Paulo) in this regard seems to be singular among the western trends of mortality: if, on one side, the cardiovascular diseases have shown declining rates ${ }^{14}$, asthma does not show an increase in its death rates, but rather a decline.

Causes for the increase in mortality are not fully understood. The arrhythmogenic action of isoproterenol prescribed in the first sprays for the treatment of asthma was initially considered as the 
main cause in an ecological study. Recently, an asthmatic cohort concluded that the use of $B 2$ adrenergic agonists when used in amounts superior to the recommended doses, was related to the rise in mortality from asthma; however, there is no relation to the overall mortality ${ }^{20}$. Other researchers stress that although there is an association, this fact does not mean that the prescription of these drugs is a marker of underestimation of the gravity of the situation both by physicians and patients?

Although popular and widely discussed, the excess of drugs does not seem to be the predominant factor in mortality, on the contrary, the lack of treatment might have greater importance, as described in the Philadelphia study, where the poorest segments were those that presented higher death rates ${ }^{\prime}$. In South Africa, different behavior was identified between whites (a declining trend) and blacks (a rising trend), explained in part by the different prevalence, but fundamentally because of the different access to medical caret.

\section{References}

1. ARMITAGE P. Statistical metbods in medical researcb. Oxford. Blackwell Scientific Publications. 1987 . p. 141-60.

2. BERRIL. W:T. Is the death rate from asthma exaggerated Eridence from West Cumbria. B.11. 306:193-4. 1993.

3. BEIST, A.S \& VOLLMER, W. Prerenting asthnta from asthma. N. Engl.J. Wed. 331: 1584-5. 1994.

4. EHRLICH, R. \& BOURNE, D. Asthma deaths among coloured and white South Africans: 1962 to 1988. Resp. hed.. 88:195-202. 1994.

5. FLNDACAO IBGE. Censo Demográfico do Estadio dé Săo Paulo, 1970. Rio de Janeiro. 1973. v.1. t.18. (89 Recenseamento Geral do Brasil. 1970)

6. FLNDAÇA IBGE. Censo Demográfico do Estado de São Panlo. 1980. Rio de Janciro. 1984. v.1. r.14. (9 Recenseamento Geral do Brasil. 1980)

- FL NDACÃO IBGE. Censo Demográfico do Estado de Sào Paulo. 1991. Rio de Janeiro. 1993 n. 21 (10\% Recenseamento Geral do Brasil. 1991).

8. FL:NDAÇO SEADE. 50 main calses of death in S. Paulo State São Paulo. 1990.

9. IXVAX, W. \& ADELSTEIX: A. Rise and fall of asthma mortalizy in England and Wales in relation to use of pressurized aerosols. Lancet. 2: 279-85, 1969.

10. IACKSON, R.: SEARS, M.: BEAGLEHOLE, R: RFA. H.I. International trends in asthma mortality 1970 to 1985 . Cbest, 94:914-9, 1988.

11. KHOT. A. \& BLRN. R. Seasonal rariation and time trends of deaths from asthma in England and Wales 1960-82, BMI. 289: 233-4. 1984.

12. LANG. D. \& POLAISKY, M. Patterns of asthma
Although the mortality from asthma has been the object of several studies, its frequency is rare $^{2}$ ( the maximal number of deaths in the period studied was of 110 ), and when a prolonged period is analyzed, the asthmatic patients with ages below 35 do not present any difference in survival in relation to the population as a whole ${ }^{19}$. The decline of the prevalence of asthma is a question that should be investigated because in other countries the rise of mortality was accompanied by a rise in prevalence, which means that there have been important consequences as regards the quality of life, expenses with drugs and hospital admissions and absences from school":

A prevalence study of asthma, a follow-up program meant for the use of emergency rooms and a surveillance of deaths due to all respiratory diseases and specifically to asthma, are three points all of which are strongly recommended for public health policy in Brazil.

mortality in Philadelphia from 1969 to 1991. N. Engl. J. hed. 331:1542-6. 1994.

13. LALRENTI. R. Doenças respiratórias como causa de morte no Município de Sào Paulo. Rev: Sulicte. Plblica, 15: 353-63. 1981.

14. LOTLFO. P. A. \& IOLIO. C. A. Coronary heart disease mortality trends in S. Paulo. Brazil. CID Epidemiol. Teusi. 49: 150-1. 1994.

15. ORGANIZACÁO MLNDIAL DA SALDE. Mamal da classificaçào estatistica intemacional de doenças, lesòes e causas de óbito: $8^{\mathrm{a}}$ revisà. 1965. Washington. DC., 1968, vol. 1.

16. ORGANIZAÇÀO MLNDIAL DA SAĹDE. Lamal da classificação estatística intemacional de doenças. lesöes e cansas de óbitos: 91 revisão. 1975. Sào Paulo. Centro da OMS para Classificaçào da Doenças em Português. 1979.

17. PLFFER. R.R. \& GRIFFITH, G.W. Patterns of urban mortality. Washington. D.C.. Organisación Panamericana de lá Salud. 1968. (OPAS-Scientific Publication 151).

18. PEREIRA, I.C.R.: STLGIYSKY, L.A; RIBEIRO. T.V.M. Assessment of strategy to control respiratory diseases in children. Ret'. Salide Puiblica, 26: 414-23, 1992.

19. SILVERSTEIX, M.: REFD, C.: O-CONNELI, E. Long-term surival of a cohort of community residents with asthma. . V. Engl f. Hed., 331: 1537-41. 1994

20. SLISSA, S.: ERNST, P.: BIOVIN. J-F.: HORWITZ R.: HABBICK, B.: COCKROFT, D.: SPITZER W. A Cohort analysis of excess mortality in asthma and use on inhaled b-agonists. Amer. J. Respir. Crit. Care Med. 149: 604-10, 1994.

21. WEISS. K.: GERGEN. P.: HODGSOX. T. An economic evaluation of asthma in the Lnited States. N. Engl. J. .hed. 326: 862-6, 1992. 


\section{Resumo}

A mortalidade por asma tem apresentado importantes variaçరes em muitos países. No Brasil, um estudo de mortalidade realizado nos anos sessenta, em duas cidades do Estado de São Paulo (São Paulo e Ribeirāo Preto) juntamente com outras dez cidades de outros paises, mostrou que São Paulo apresentava menor coeficiente de mortalidade por asma. Foi teito novo estudo da mortalidade por asma na população do Estado de São Paulo com Idade entre 5-34 anos. Foram analisadas as bases de dados do sistema oficial de mortalidade do Estado de Săo Paulo. Para seleçāo dos dados de mortalidade foram escolhidos os códigos 490 a 493 da Classificaçāo intemacional de Doenças de 1970-1978 (CID-8) a 1979-1992 (CID-9). Os coeficientes por asma apresentaram padrão oscilatónio declinante durante os 23 trés anos de observação, com um pico de obitos nos anos inicials. O cálculo dos coeficientes de correlaçáo, que foram negativos, sugere declínio da mortalidade no periodo, principalmente na faixa etária dos 5 9 anos e na dos 30-34 anos. A segmentaçâo dos dados entre os períodos de 1970-78 (ClD-8) e 1979-92 (CID-9) mostrou estabilidade em cada período, em todas as faixas etarias, exceto a $5-9$ anos no periodo de $1970-78$. Comparando os coeficientes ajustados entre os 5 e 34 anos no Estado de Säo Paulo $\theta$ as respectivas tendencias com catorze paises, obteve-se padrāo intermediário.

Asma, mortalidade. Coeficiente de mortalidade. 